\title{
Yale Honors Book-Collecting and Librarianship
}

$\mathrm{O}$ N THE eighteenth and nineteenth of October, to mark the return of the institution to peacetime pursuits and to call attention anew to its notable collections in the fields of letters, science, and the fine arts, Yale University gave a series of receptions and exhibitions and culminated the week-end with a convocation honoring librarians, collectors, and museum curators by conferring honorary degrees on twelve distinguished representatives of these fields from various parts of the United States. At a reception on the afternoon of the eighteenth at the Peabody Museum of $\mathrm{Na}$ tural History, a mural by Rudolph Zallinger in the Great Hall of Reptiles, depicting life in the Mesozoic age in what is now Montana was unveiled together with a series of dioramas by Perry Wilson on the flora and fauna of Southern New England. The same evening there was a reception in the Yale Art Gallery, the opening of a special exhibition of paintings, prints, and sculpture, and an address by William M. Ivins, Jr. Saturday afternoon there was a reception in the rare book room of the Sterling Memorial Library at which three hundred of Yale's choicest and rarest printed books were exhibited, many of them, not in cases, but on tables where they could be picked up and examined. Coincident with these festivities the Yale University Press published a handsome fifty-page illustrated volume on The Yale Collections, which was presented to guests.

The convocation on Saturday evening in
Woolsey Hall was opened by President Charles Seymour, who spoke feelingly, in a brief address of welcome, of the good fortune of Yale and the other institutions of America in being spared the devastation visited upon so many universities and cultural centers of the old world. He pledged that with the opportunity afforded by the return of peace, Yale would "go forward with the essential mission of a university, which is to preserve and to strengthen the civilizing aspects of human life."

The convocation address was made by Lawrence C. Wroth, librarian of the John Carter Brown Library of Brown University, who spoke on "The Validity of Antiquarianism." In paying tribute to those who through the past and into the present have assembled great private and public collections of books, manuscripts, works of art and of natural history, Mr. Wroth said :

The men who make and serve museums and libraries certainly are truly happy men. These men, the makers and administrators of museums and libraries, are free men, above the necessity for judgment between good and evil. It is theirs merely to assemble and arrange the evidence.

They are happy in believing that the greater the body of evidence in hand and the clearer the record it establishes of the past the more merciful, the juster, will be the judgments and the more intelligent the programs for the future.

The candidates for honorary degrees were presented to President Seymour by the Pub- 
lic Orator, Chauncey Brewster Tinker, Keeper of the Rare Books of Yale University and Sterling Professor of English Literature, Emeritus. Professor Tinker used the following citations in presenting Henry Raup Wagner, bibliophile and author, Lawrence Counselman Wroth, 1ibrarian of the John Carter Brown Library of Brown University, Keyes DeWitt Metcalf, director of the Harvard University Libraries, Harry Miller Lydenberg, director emeritus of the New York Public Library, and Luther Harris Evans, Librarian of Congress :

\section{Henry Raup Wagner}

Mr. President, I have the honour to name for the degree of Doctor of Humane Letters, the bibliophile and author, Henry Raup Wagner, in absentia. A graduate of Yale College in the class of 1884 .

This celebration would be neither representative nor complete without the recognition of the private collector himself, for is he not the flowing source from which great libraries and museums derive their sustenance? I do not say that Mr. Wagner is the greatest of collectors, but that he is the most typical. Book-collecting has been his chief and abiding occupation. His relentless pursuit has been carried on through five successive decades and during his residence in three different continents. Thus he has become a citizen of the world. $\mathrm{He}$ is a part of all that he has met, and whatever he has met has been utilised to develop his skill as a collector. $\mathrm{He}$ has known every dealer, every librarian, and every bibliographer of his time. $\mathrm{He}$ has sought for books in Chile and in Guatemala.

During his residence in England he gathered the ten thousand volumes that constitute his great collection of tracts on British and Irish economics and trade from 1600 onwards. An even larger collection of books on Mexico was formed during his residence in that country. His regular business affairs seem never to have interfered with the exhaustive study of his books-a study resulting in the publication of bibliographies definitive in character.

It was impossible for Mr. Wagner to keep all the collections that he formed, since it would have required a castle to contain them. He therefore gave or sold them to the great libraries of the country, and thus wrote his name large in the history of the Huntington, the library of the University of Texas, and many others. Four such collections, including the two I have mentioned, were received by the Yale library during the twenty-one years from 1915 to 1936 .

His reputation as a collector is surpassed only by his skill as a bibliographer. A mere "checklist" of his publications covers some sixteen pages. His autobiography bears the significant title, Bullion to Books; but his reputation in future will repose rather on the latter element than on the first.

\section{Lawrence Counselman Wroth}

Mr. President, I have the honour to name for the degree of Doctor of Humane Letters, the librarian of the John Carter Brown Library of Brown University, Lawrence Counselman Wroth, the speaker of the evening.

Mr. Wroth is the connecting link between the mad collector and the sane librarian. His skill in this benign mediation springs from his scholarship in bibliography, the art of detecting and recording the origin, reliability, and interrelation of books, for the use of future scholars. It aims to set in order the whole body of information on a particular subject and thus to promote sound learning. $\mathrm{Mr}$. Wroth is never weary of showing that it is the collectors who make possible the great libraries, such as the Morgan, the Folger, the Huntington, and his own John Carter Brown library.

Book-collectors are first laughed at for their childish hobby, as though on a plane with boys who make stamp albums or collect birds' eggs. As mature spirits they might have been expected to lay aside such trifling amusements. But at last, when a collection has become so comprehensive that even a scholar can no longer neglect it, the man who has created it attains a sudden prominence. $\mathrm{He}$ is then praised for his acumen and foresight, since, as a result of his madness, precious facts have been rescued from the dark backward and abysm of time. $\mathrm{He}$ is then praised as one who has preserved documents and original information which others in their fine 
indifference have passed by as of no account.

Because Mr. Wroth can appreciate and defend collectors his name is written on their grateful hearts. To be in his presence is to share his zest for the subject. The very title of his fine essay, The Chief End of Book Madness, is indicative of the service he renders, for it implies that the book-collector has an end and aim. Of that end and aim, the libraries of the country are the beneficiaries.

In all his writing there is clarity and charm, but nothing "punchy." $\mathrm{He}$ assumes the presence of an audience at once mature, fairminded, and educated-an audience, in other words, like unto himself.

\section{Keyes DeWitt Metcalf}

Mr. President, I have the honour to name for the degree of Doctor of Humane Letters the Director of the Harvard Libraries, Keyes DeWitt Metcalf.

Mr. Metcalf has been at the Harvard College Library since 1927 , before which time he had been in the staff of the New York Public Library, where he had succeeded Mr. Lydenberg as chief of the Reference Department.

In Cambridge he became the custodian of a tradition which had been active through three centuries. Interrupted in 1764 by the fire which destroyed the college library, its preeminence was re-established in the 19th century. Since then, among universities, it has set the pace and drawn other institutions into keen and fruitful rivalry with it. Stimulos dedit aemula virtus.

We at Yale have never forgotten our relation to the elder sister, from whom we are not ashamed to learn; indeed, to a certain healthy rivalry with it, we owe a stimulus which is ever present in our minds.

Assured of worthiness, we do not dread Competitors, we rather give them hail, And greeting in the lists where we may fail.

Mr. Metcalf presides over seventy-seven different libraries in Cambridge, containing a total of four and a half million titles.

$\mathrm{He}$ is not a man of many words. It is related that on a social occasion in a South American land, when library affairs were being generally discussed, a lady of great social distinction and some learning, suddenly interrupted a lively conversation with the telling words, "Mr. Metcalf has spoken." It was a pregnant admonition; for on those rare occasions when Mr. Metcalf speaks out, we should all do well to listen.

\section{Harry Miller Lydenberg}

Mr. President, I have the honour to name for the degree of Doctor of Humane Letters the Director Emeritus of the New York Public Library, Harry Miller Lydenberg.

His staff at the New York Public remember him, not as a remote administrator seen but seldom among the workers, but as the one among them who (a) knew the books; who (b) had an expert's knowledge of everything relating to the manufacture of printed books, paper, ink, print, binding, lettering, and engraving, and, in particular, to their care and protection; and who (c) knew the whole history of the triune institution which the New York Public had become. He linked it back to the days of Dr. Billings and the old Astor and Lenox libraries. He had begun his career by cataloguing books in the latter.

During his connection with that greatest of public libraries, it was shown that a harmonious operation might take place between two apparently opposed conceptions, that of a popular library - a library for the peopleand a scholar's library-a library for the student. His task was, moreover, to build up and round out the reference collections, a work which, in the opinion of his peers, was never equalled anywhere.

One month after his retirement in October 194I, he accepted the post of Director-Librarian of the Biblioteca Benjamin Franklin in Mexico, where an attempt was being made to put modern books, largely in a foreign tongue, before a cultured, sophisticated community with rich collections of its own.

In August 1943 he assumed the directorship of the American Library Association's Board on International Relations and in January last went to Europe as a member of the $\mathrm{Li}$ brary of Congress Mission. Its object was to speed the flow of books from Germany to American libraries, to study library conditions there and elsewhere; and to promote a normal intercourse among libraries, universities and learned societies. In Europe, as formerly in New York, his modest and eager personality, his youthful mind and spirit, his warm and 
inspiring friendship became of international influence.

\section{Luther Harris Evans}

Mr. President, I have the honour to name for the degree of Doctor of Humane Letters, the Librarian of Congress, Luther Harris Evans.

No higher compliment could be paid to our national librarian than the announcement that his election, occurring as it did after the passing of the comet, was the most natural one that could be made. After years of service in the Library, he succeeded, with complete appropriateness to the custodianship of the American record. As he has himself remarked, the outlook of the high office to which he had risen was once upon the Capitol building itself, as though to remind the librarian that his services were to be primarily, and perhaps exclusively, devoted to the needs of the Congress. In his latest utterance he has transcended but by no means excluded this view of the institution. "Libraries," he remarks, "make men realise the greatness of the past achievements of the human race and the source of our strength for the morrow."

The Librarian of Congress is servus servorum, the leader in a vast fellowship which extends its assistance to other libraries in the form of printed catalogue cards, "union lists," bibliographies, loans, and, above all, in its example as promoting the "enlightenment and welfare of the human family." In its vast treasury, no language is lacking and no country unrepresented.

It is a comfort to repose our trust in one who has no terror of the Congressional Record or of the continuous stream of copyrighted books, in one who can think in terms of shelves extending for hundreds of miles, and of annual accessions in millions. Mere size does not confuse his thinking, but

Pleased the nation's service to perform, $\mathrm{He}$ rides in the whirlwind and directs the storm.

When President Seymour had conferred the last degree and Mr. Tinker had resumed his seat, Wilmarth Sheldon Lewis, fellow of the Yale Corporation and chairman of the Yale University Council on the
Library and Museums, surprised the audience and Mr. Tinker by stepping forward and presenting him for a similar honor:

Mr. President [said Mr. Lewis], I have the honor to present for the degree of Doctor of Letters, the Keeper of Rare Books and Sterling Professor of English Literature, Emeritus, Chauncey Brewster Tinker.

When Mr. Tinker entered Yale as a freshman fifty-one years ago the bells of Battell should have celebrated his arrival, for few Yale men have ever had a happier influence upon their alma mater. For forty-two years he taught the students of the university; for ten college generations and more he led them through the streets and courts of Johnson's London and he opened to them the magic casements of poetry. From one end of this country to the other are men who think of Boswell, Wordsworth, Matthew Arnold, and, above all, Shakespeare, in the words and accents of this master-teacher. Many of these men are themselves teachers treading the paths opened or widened by Mr. Tinker who has ever been a pioneer in research; many more are men whose lives are spent far from these paths, but who carry with them the memory of a beauty and an excitement brought to them long ago in A One Osborne Hall or in the topless tower of Phelps Gateway.

But, Mr. President, Professor Tinker stands before you tonight not only as a teacher and a scholar; he stands before you in another character, as well: the champion of the Yale Library, its benefactor and dedicated servant. His address on Alumni Day, 1924, opened a new era in the university's history, for he brought home to the Yale community the fact-so easily lost sight ofthat the foundation upon which a university rests is its library. The Yale Library, we learned, is one of the great libraries of the world and should be honored by all those who wish the university well. Nay, more, he said, it should be supported, in fact, enriched by all who wish the university well. They should load it with treasure as the men and women of the Middle Ages adorned their cathedrals to the greater glory of God.

His words were heard. Graduates and friends of Yale, led by his precept and ex- 
ample, discovered the library to be a place of inspiration and enchantment. They were, they found, the latest in a devoted band of men and women who for upwards of two and one-half centuries have brought to Yale the materials of -scholarship which a university must have if it is to fulfill its high purpose.

This convocation signalizes one moment in that endless expression of aspiration and faith. Yale has been happiest when the collector, the custodian, and the scholar have been in harmony. These three are rarely met in one person, but such a man, Mr. President, comes before you now, applauded by his old students and colleagues and the friends of libraries and museums and of learning wherever they may be found.

Six other curators or directors of museums were also awarded honorary degrees.
The Yale Collections by Wilmarth S. Lewis $^{1}$ is a book which highlights all that was said and done at the ceremonies we have described, and its accounts of Yale's possessions in books, manuscripts, paintings, silver, furniture, textiles, ancient art, natural history, and anthropology are sufficient to drive anyone in a less-favored institution into a state of quiet despair. There are chapters on the library, the art gallery, the Peabody Museum of Natural History, and the anthropological museum, in which the history and development of each is traced and some account is given of the more notable of the individual collections acquired by gift or purchase by which they have been built up.

${ }^{1}$ New Haven, Conn., Yale University Press, 1946.

\section{What Do the Members of A.C.R.L. Want?}

\section{(Continued from page 10)}

the minority groups in even a worse position than at present. The question would legitimately be raised, why should any group such as the A.C.R.L. remain within the A.L.A. if it is to collect its own dues irrespective of A.L.A.? It would be far better to have an association of college, university, and reference librarians with its own branches in the various states uniting with other groups in the state for action on state and local affairs. If the proposal for universal membership mentioned above should become a reality, the strangle hold upon the minority groups would become complete. The only solution in such a case would seem to be to build up an organization for the larger minority groups similar to that of S.L.A.

All members of the A.C.R.L. committee want a strong national association representing the entire library profession but with autonomy for special groups in the management of their own affairs and with the privilege of deciding upon the general activities of value to their groups. This is democracy. The original proposals were designed to point the way for the formation of a strong national association representing all special groups. Eyen the proposal to form in six months a separate association of college and university librarians unless the A.L.A. was willing to discuss the proposals of the committee was made with the idea as expressed by one member that "temporary separation from the A.L.A. may be the most satisfactory method of bringing to the attention of A.L.A. the need for a radical change in the national organizations of libraries and librarians." The committee believed that the development of a strong national association as a holding corporation in the autonomy for special groups, with decentralized control, with a much greater participation by a much larger proportion of the membership is necessary for the successfull advancement of librarianship in the U.S. 